\title{
The Ends of Weather: Teleology in Renaissance Meteorology
}

\author{
C R A I G M A R T I N*
}

I .

THE DIVIDE BETWEEN THE prominence of final causes in Aristotelian natural philosophy and the rejection or severe limitation of final causation as an acceptable explanation of the natural world by figures such as Bacon, Descartes, and Spinoza during the seventeenth century has been considered a distinguishing mark between pre-modern and modern science. ${ }^{\mathrm{I}}$ Admittedly, proponents of the mechanical and corpuscular philosophies of the seventeenth century were not necessarily stark opponents of teleology. Pierre Gassendi and Robert Boyle endorsed teleology, Leibniz embraced entelechies, and they creep into Descartes's natural philosophy, despite his adamant attempts to eliminate them. ${ }^{2}$ Nonetheless, critiques of ends in natural philosophy resonated throughout seventeenth-century natural philosophy and beyond. Enlightenment figures such as Jean le Rond D'Alembert ridiculed the use of teleology to explain the natural world. ${ }^{3}$ Dennis Des Chene,

${ }^{\mathrm{I}} \mathrm{F}$. Bacon, De augmentis scientiis, in Works, ed. J. Spedding, R. L. Ellis, and D. D. Heath (London: Longman, I 8 57), I:57 I; R. Descartes, Principia philosophiae I.28, in Euvres, ed. C. Adam and P. Tannery (Paris: J. Vrin, I986), 8-I: I 5; B. Spinoza, Appendix to Ethics I, in The Collected Works of Spinoza, trans. and ed. E. Curley (Princeton: Princeton University Press, I985), 439. For the importance of the rejection of final causes in the historiography of the Scientific Revolution, see Alexandre Koyré, Newtonian Studies (Cambridge, MA: Harvard University Press, I965), 7-8; Steven Shapin, The Scientific Revolution (Chicago: Chicago University Press, I996), 28-30. For an overview of the Scientific Revolution and scholastic views of teleology see Monte Ransome Johnson, Aristotle on Teleology (Oxford: Oxford University Press, 2005), 23-30.

${ }^{2}$ Margaret Osler, "From Immanent Natures to Nature as Artifice," The Monist I9 (I996): 388-407; Margaret Osler, "Whose Ends? Teleology in Early Modern Natural Philosophy," Osiris, 2nd series, I 6 (200I): I 5 I-68; Timothy Shanahan, "Teleological Reasoning in Boyle's Final Causes," in Robert Boyle Reconsidered, ed. Michael Hunter (Cambridge: Cambridge University Press, I994), I77-92; Alison Simmons, "Sensible Ends: Latent Teleology in Descartes' Account of Sensation," Journal of the History of Philosophy 39 (200I): 49-75.

3 'Denis Diderot and Jean le Rond D'Alembert, Encyclopédie ou Dictionnaire raisonné des sciences, des arts et des métiers (Paris: Briasson, I75I), 2:789.

* Craig Martin is Assistant Professor of History at Oakland University.

Journal of the History of Philosophy, vol. 48, no. 3 (2010) 259-282 
however, has effectively demonstrated that Descartes's and others' characterization of early-modern Aristotelians as positing intention into non-rational or even non-sentient agents did not reflect their true position. ${ }^{4}$ Des Chene's view holds for sixteenth- and seventeenth-century Aristotelians, which he treats with much skill and subtlety through exploring philosophical arguments mostly found in discussions of the Physics and Metaphysics.

Nevertheless, the examination of teleology in late Aristotelianism is by no means exhausted, particularly with respect to debates over how far its applicability extended within the natural world. Consideration of this question illustrates the relationship of different camps of Aristotelians to religious concerns, the purposes of universities, and methods of reading Aristotle. Debates over teleology were especially evident in considerations of meteorology, a field that demanded causal explanations of irregular and at times intractable phenomena. This field did not consider souls, ordered nature, or, according to some interpretations, even substantial forms. As a result, the field is particularly pertinent to questions over the nature and extent of final causation in Aristotle, issues that are much debated in contemporary scholarship. Similarly, Renaissance Aristotelians debated the role of final causes in natural philosophy and perhaps had even more divergent views on the topic than are found in modern interpretations of Aristotle. Nevertheless, early-modern concerns found in treatments of meteorology partially correspond to recent discussions, some of which assert that, according to Aristotle, seasonal rains are teleological, perhaps in an anthropocentric sense, whilst others contend that Aristotle's teleology is limited to natural kinds. ${ }^{5}$

The doubts over final causes in meteorology are heightened by the fact that there is little, if any, discussion of teleology in Aristotle's Meteorology. The apparent absence of the consideration of final causes, while shifting much discussion to material and efficient causation, led some sixteenth-century natural philosophers to question whether the Aristotelian doctrine could be improved by inventing or discovering final causes, which Aristotle himself did not describe. They asked whether, even if meteorological phenomena were accidental in their nature, composed of imperfect mixtures without their own substantial forms, they might not have a larger purposive role in the universe or in human affairs. While the necessity of rain for agriculture might obviously point to an anthropocentric purpose, the ends of meteorologically provoked disasters are less clear or even dubious. What is the purpose of a destructive storm or flood? Answers to these questions were inevitably linked to theological and ethical concepts; and the character of these answers in the sixteenth century largely differed according to the confessional divide between Protestants and Catholics.

${ }^{4}$ Dennis Des Chene, Physiologia: Natural Philosophy in Late Aristotelian and Cartesian Thought (Ithaca, NY: Cornell University Press, I996), I68-2 I I.

${ }^{5}$ For the view that seasonal rains have final causes see David Furley, "The Rainfall Example in Physics II.8," in Cosmic Problems (Cambridge: Cambridge University Press, I989), I I 5-20. For the view that these purposes are anthropocentric, see David Sedley, "Is Aristotle's Teleology Anthropocentric?", Phronesis 36 (I99I): I79-96. For the rejection of this view see Robert Wardy, "Aristotelian Rainfall or the Lore of Averages," Phronesis 38 (I993): I8-30; Johnson, Aristotle on Teleology, I49-58. 
The difficulty and uncertainty engendered by meteorology made it possible for authors from Italy, influenced in part by medieval theology, to contrast the limitations of human knowledge to God's absolute power. For them, meteorology was evidence of the inability of humans to understand the purpose of the accidental, contingent properties of matter. While this inability could cut short discussions of the teleology of meteorology, some natural philosophers took this as evidence of the non-deterministic character of the natural world, which ultimately depends on God's will. Divine power extends not just to substances, but to accidents as well through secondary causes. Even if it is not possible to grasp God's precise intentions, these accidents are purposeful because they are part of the divine ordering of the universe.

A number of sixteenth-century Lutheran philosophers expounded on the final causes of the weather in lengthy and sophisticated discourses with greater certainty than did most professors working in Catholic lands. They often saw meteorological phenomena as proof of divine providence or God's wrath. In a reworking of Aristotelian concepts of teleology, meteorology's final causes were evident not only in the necessary links between benign weather and human welfare, but also in the seemingly portentous nature of rare and violent events. Lutheran authors saw meteorological events as prophetic signs, which found their purpose in the foreshadowing of the future. Lutherans' utilization of final causes emerged from the self-conscious attempt to fuse natural philosophy with theology. This goal dominates the works of Nicolaus Taurellus, who, in his book-length attack on the Italian professor of botany and medicine Andrea Cesalpino, disputed Cesalpino's contention that meteora do not have final causes. ${ }^{6}$ In contrast, Taurellus thought the failure to see purpose in nature was emblematic of the kind of natural philosophy practiced in Italy often by laymen (as most Italian professors were), who considered natural philosophy propaedeutic to the study of medicine and largely distinct from theology. ${ }^{7}$ Views similar to Taurellus's were widespread but not universal among Lutherans. Nonetheless, disputes about the relation between natural philosophy, metaphysics, and theology rendered positions diverse. For example, Jacob Schegk and Georg Liebler, both of whom taught natural philosophy at Tübingen, did not emphasize the examination of teleology in their treatments of meteorology. In contrast, professors at Wittenberg, such as Johannes Garcaeus and Wolfgang Meurer, not only utilized final causes but also categorized the purposes of meteorology as either physical or theological. Physical final causes were typically anthropocentric or concerned with the functioning of the universe. Theological final causes were found in the meaningfulness of weather. Garcaeus and Meurer considered the purpose of rare or violent weather events to be found in their prophetic nature; they were signs of God's will, which could be at times providential and at times wrathful.

${ }^{6}$ Nicolaus Taurellus, Hoc est, Andr. Caesalpini Itali, monstrosa $\mathcal{E}$ superba dogmata, discussa Ẽ excussa (Frankfurt: M. Z. Palthenius, I 597), 99. For Taurellus' subsequent influence on this particular issue, see the dissertation from the University of Leipzig: Joannes Schreiner [praeses], Disputata meteorologica de pluvia (Leipzig: G. Kirsch, I626), B4r.

${ }^{7}$ Peter Petersen, Geschichte der aristotelischen Philosophie im protestantischen Deutschland (Leipzig: F. Meiner, I92I), 219-58. 
Although the teleology of natural philosophy was often related to religious issues, many Italian authors questioned whether meteorological phenomena were purposeful for other motives. Taurellus was correct in proclaiming that lay scholars working in Catholic lands, such as Italy, were more likely to dispute the applicability of final causes to meteorology. Their doubts, however, resulted not just from their lay status, but also from their desire to attempt to interpret Aristotle's texts literally. Discussions of final causes for meteorology added little to a literal or historically-minded reading of the text of the Meteorology. Nevertheless, the attractiveness of systematizing, considerations of meteorological phenomena as a necessary part of the universe, theological considerations, and open disagreement with Aristotle prompted Italian natural philosophers to discuss the possibility of final causes for some meteorological phenomena.

$$
2 \text {. }
$$

Aristotle wrote his natural philosophical works attacking, among others, Presocratics, whom he considered to be materialist and determinist. Empedocles and Democritus failed, in his eyes, because they thought that the principles of necessity and chance were sufficient explanatory tools for all of the products of nature. For Aristotle, much of the content of the universe was clearly the result of design. Instead of utilizing the idea of a designer or craftsman, as Plato had done in the Timaeus, Aristotle linked the idea of design with nature, or phusis, which served as a directional agent. In his view, nature in general is the regulating principle of the universe. Each natural body also possesses its own phusis, which is its internal source of motion and growth. The completion (teleiōsis) of this motion, such as the growth of animals into adults or the natural motion of the elemental bodies into their natural places, can be understood as a fulfillment of an intrinsic purpose. Cosmic order, nature's regularity, and fixed species of living things were taken as signs that the world was neither the product of chance nor merely the result of a random arrangement of atoms. The degree of order and regularity, however, was not uniform throughout the universe.

For Aristotle, the motions of the celestial bodies were most ordered, moving perpetually in circles. Even though the motion of these bodies causes change in the sublunary realm, change is less ordered below the moon. In De generatione et corruptione 2.IO, Aristotle argued that the motion of the sun around the ecliptic caused the elements to transform themselves cyclically. This motion is ultimately the producer of all generation and decay on earth. According to Aristotle, because the sun moves on the ecliptic, it is thereby either approaching or retreating from the earth and "its movement will be irregular." ${ }^{8}$ The impermanence and relative disorderliness of the sublunary realm is the result of the irregular motion of the sun. The proximity of the sun causes generation, while its remoteness causes destruction. Additionally, generation and corruption are irregular because of the matter of the terrestrial world: "For their matter is irregular ... hence the processes by

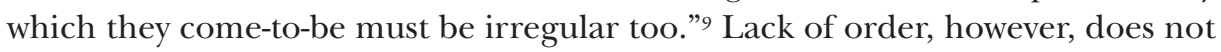

\footnotetext{
${ }^{8}$ Aristotle De generatione et corruption $[G C]$ 2.10.336a33-b6, trans. H. H. Joachim (Princeton: Princeton University Press, I984)

${ }^{9}$ Aristotle, GC 2.10.336b22.
} 
necessarily entail a complete lack of perfection. Rather, according to Aristotle, God "fulfilled the perfection of the universe by making coming-to-be uninterrupted." Therefore cycles of generation and destruction lead to the perpetual being and creation that participates in the perfection of the universe.

While nature strives for the best, and purpose is found throughout nature, not everything is purposeful in itself, even if it is part of the general cyclical nature of the sublunary region. Rather, some things are the result of material necessity, namely, what arises from the dispositions of matter alone. Aristotle gave perhaps the clearest example in De generatione animalium in his discussion of eye color. Eyes clearly have final causes since their proper functioning allows for sensation. The color of the eye is not always purposeful, however, because it typically is not related to the functioning of the eye or to the essence of the eye's possessor. In order to understand eye color "we must refer the causes to the material and the motive principle on the view that these things come into being by necessity." ${ }^{\text {I }}$ The accidental properties of the eye come out of a simple material necessity, an unqualified ( $h a p l o \bar{s}$ ) necessity, and the color itself has no purpose, not being the result of the realization of the nature of either the eye or the animal. As a result, knowledge of the eye's color comes only from an understanding of the properties of matter and cannot be placed within the larger context of the particular organism, its species, or the order of the universe.

Potentially, large portions of meteorological phenomena can be seen as accidental, that is, caused by material necessity alone. The first three books of Aristotle's Meteorology are almost completely, if not completely dedicated to explanations via material and efficient causation. ${ }^{\mathrm{I}}$ Final and formal causes typically are not part of his explanations for these subjects, because the matter of meteorological phenomena is perpetually imperfect, being partial transformations of the elements, as numerous medieval and Renaissance commentators noted. Moreover because these partially transformed elements are inanimate, as the sixth-century commentator Olympiodorus argued, they do not participate in the formation of organs and organism, which have clear purposes and ends. ${ }^{13}$ During the Middle Ages and Renaissance, most Aristotelian commentators described the subject of the Meteorology as that of "imperfect mixtures." Meteorological phenomena were considered imperfect because they were composites of the elements that had not transformed into a new substance. The forms of the elements remain, thus rendering meteorological phenomena without their own essential natures and substantial forms independent from the four elements. The imperfection of meteorological phenomena rendered discussions of their teleiosis contradictory if not impossible

${ }^{10}$ Aristotle, $G C$ 2.10.336b3 I-32.

${ }^{11}$ Aristotle, De generatione animalium 5.I.778a32-778b2, trans. A. Platt (Princeton: Princeton University Press, I984).

${ }^{12}$ For possible discussions of final causes see Aristotle, Meteorology 2.3.359aI 5 and 359bI 5; CristinaViano, La matière des choses le livre iv des Météorologiques d'Aristote et son interprétation par Olympiodore (Paris: J. Vrin, 2006), I43.

${ }^{13}$ On Meteorology I-3 as about inanimate homeomerous substances, see Olympiodorus, In Aristotelis meteora commentaria, in Commentaria in Aristotelem graeca, vol. I2-2, ed. G. Stüve (Berlin: G. Reimer, I900), 273, 11. 20-2I. 
because they lacked the intrinsic end of the realization of their form. Nevertheless, although Aristotle did not rule out the possibility that meteorological phenomena have an extrinsic purpose, whether anthropocentric, or in the participation of perpetual being, he neither discussed what these extrinsic purposes might be nor explicitly eliminated them.

Aristotle's followers in the Renaissance faced a dilemma. The failure of the Meteorology to discuss teleology, the irregular and even noxious character of many meteorological phenomena, and the understanding of them as being caused by imperfect mixtures suggested that the field of meteorology could dispense with final causes. At the same time, however, Aristotle could cite much evidence that there is some order and purpose to the weather. Seasonal rains ensure the availability of crops, and climatic and seasonal weather patterns not only exist, but are necessary for human survival. ${ }^{\mathrm{r}}{ }^{4}$ The lack of consideration of final causes in the Meteorology does not necessarily mean that Aristotle rejected their existence outright. Moreover, Christian emphases on God's will, providence, and creation further complicated Renaissance discussions of the purpose of meteorology, since the idea that weather phenomena was without order suggested limitations both to God's power and to God's involvement with the mundane.

3 .

While professors in universities in France, Spain, and other Catholic countries taught meteorology during the sixteenth century, the strength of Italian universities and their emphasis on medicine and natural philosophy, rather than theology, and their teaching methods that depended on explication of Aristotle's text instead of paraphrases contributed to the production of some of the most detailed and sophisticated commentaries on the Meteorology in all of Europe during the Renaissance.$^{15}$ Moreover, the lay status of Italian professors, coupled with their willingness at times to separate the study of nature from theology, made them emblematic for Lutherans, such as Taurellus, of a heretical version of natural philosophy. ${ }^{16}$ Renaissance Italian meteorological writings, however, offer complex attitudes to many questions, utilizing a range of theological and patristic writings and medieval commentaries as authorities, while still engaging in careful philological analysis.

Many late-medieval and Italian Renaissance meteorological treatises followed Aristotle and simply omitted teleology or discussed it in an extremely limited

${ }^{14}$ See Aristotle, Physics 2.8. I9 8b 6 6-2 I. Whether Aristotle actually endorsed a teleological position in this case has been a matter for debate.

${ }^{15}$ For the prominent position of natural philosophy based on Aristotelian texts in Renaissance Italian universities see Paul F. Grendler, The Universities of the Italian Renaissance (Baltimore: Johns Hopkins University Press, 2002), 267-3 I3. For the importance of paraphrastic writing on Aristotle in France, see Eckhard Kessler, "The Lefèvre Enterprise," in Philosophy in the Sixteenth and Seventeenth Centuries: Conversations with Aristotle, ed. Constance Blackwell and Sachiko Kusukawa (Aldershot: Ashgate, I999), I-22; Eugene F. Rice, Jr., "Humanist Aristotelianism in France: Jacques Lefèvre and his Circle," in Humanism in France at the End of the Middle Ages and in the Early Renaissance, ed. A. H. T. Levi (Manchester: Manchester University Press, I970), I32-49.

${ }^{16}$ For the separation of philosophy from, as well as its subordination to, theology in the Italian tradition, see Ian Maclean, "Heterodoxy in Natural Philosophy and Medicine: Pietro Pomponazzi, Guglielmo Gratarolo, Girolamo Cardano," in Heterodoxy in Early Modern Science and Religion, ed. John Brooke and Ian Maclean (Oxford: Oxford University Press, 2005), I-29. 
manner, without explicitly rejecting the existence of final causes for this field. Some simply go back to some of the commentaries of the twelfth and thirteenth centuries. Averroes had distinguished the subject of meteorology as that which considers what has been produced by the dual exhalations, while other books, such as the De partibus animalium, looked at simple and complex substances with regard to final causes. ${ }^{17}$ Albertus Magnus, whose writings included one of the most influential medieval commentaries on the Meteorology, made clear by the title of his treatise that his work was an examination of material and efficient causes. ${ }^{18}$ The dedication of the treatise to these kinds of explanations does not entail an ontological rejection of final causation for this class of phenomena, but nevertheless is reflective of the understanding of meteorological phenomena as imperfect.

Silence or near silence on the issue of final causes characterizes a number of these later treatments. Gaetano of Thiene, a professor at Padua and the author of one of the earliest printed commentaries on the Meteorology, seems not to have mentioned final causes at all. ${ }^{19}$ In the middle of the sixteenth century, Francesco Vimercati, originally from Milan but later a professor at the Collège Royal in Paris, continued in this tradition in his commentary on the Meteorology, which was based on his reading of Aristotle in the original Greek. He described meteorology as having just two principles and common causes, the material and efficient. ${ }^{20}$ Andrea Cesalpino's Peripateticarum quaestionum libri, first printed in I 57 I while he was a Professor at Pisa, looks solely at the powers of the sun and the nature of the underlying material in a question about the effects of the heavenly bodies on the formation of vapors and rain and contends that the transformation of the elements into inanimate beings occurs out of material necessity. ${ }^{21}$

This silence, however, was not universal. Perhaps the most nuanced discussion of teleology in sixteenth-century meteorological writings is found in the work of Pietro Pomponazzi. His discussion of this topic supports recent reevaluations of his work, especially that by Rita Ramberti, who understands Pomponazzi as attempting to explore naturalistic explanations whilst maintaining that the Christian faith possesses the mysterious and ultimate truths about the universe. ${ }^{22}$ Moreover, the Pomponazzi that emerges from his meteorological writings is one that is looking

${ }^{17}$ Averroes, In quatuor meteorologicorum Aristotelis libros, in Aristotelis opera (Venice: Giunta, I 572-76), $5: 403 \mathrm{r}-04 \mathrm{v}$

ı "Tractatus primus de causis impressionum omnium, materiali et efficiente." Albertus Magnus, Meteora, in Opera omnia, vol. 6-I, ed. P. Hossfeld (Münster: Aschendorf, 2003), I.

${ }^{19}$ Gaetano of Thiene, In quattuor Aristotelis metheororum libros expositio (Padua: M. Maufer, I476).

${ }^{2 \circ}$ Francesco Vimercati, In quatuor libros Aristotelis Meteorologicorum commentarii (Paris: Vascosan, I 556), I4: Quod ideo facit, ut eiusmodi rerum, quae in sublimi oriuntur, principia, Ẽ causas communes, quae duae sunt, materia, Ẽ agens, scrutentur.

${ }^{21}$ Andrea Cesalpino, Peripateticarum quaestionum libri quinque (Venice: Giunta, I 57 I), 2 IV, 64V$67 \mathrm{r}$.

${ }^{22}$ Rita Ramberti, "Stoicismo e tradizione peripatetica nel De fato di Pietro Pomponazzi," Dianoia 2 (I997): 5 I-84. For an excellent account of the historiography of Pomponazzi, see 5 I-62. For the foundations of modern scholarship on Pomponazzi, see Bruno Nardi, Studi su Pietro Pomponazzi (Florence: Le Monnier, I965). 
backward, engaged with the medieval theological tradition, not an advocate for radicality or initiating the first steps toward modern science..$^{23}$

In Pomponazzi's eyes, the impossibility of complete knowledge of the sublunary world is evident as the result of problems of understanding the purpose of meteorological phenomena. This difficulty is twofold. In Meteorology 4.I 2, Aristotle argued that composite substances, such as organs, could be better known than simple homogeneous substances or the elements because their function could be related to their form and structure. Thus the purpose of organs could be known better than simple substances, or in the words of Pomponazzi: "These homogeneous stuffs, such as metal, are known less than organic ones . . . because they have less of form and more of matter; for they are closer to matter and more distant from form." ${ }^{24}$ Similarly, knowledge of meteorological phenomena is limited because they are inorganic and closer to matter than form. Second, the difficulty of discovering final causes is increased by the seemingly destructive nature of extreme meteorological phenomena. If meteorological phenomena have anthropocentric purposes, it must be explained how cataclysmic weather events are necessary for human well-being.

Pomponazzi's inquiries into the teleology of meteorology were made more inconclusive because of Aristotle's silence. Pomponazzi noted this silence on the question of the purpose of winds and earthquakes, which were considered to be caused by winds, and opposed it to Seneca's teleological discussion of these subjects found in his Natural Questions. Pomponazzi suggested that the discussion should center on extrinsic ends, that is, not the realization or perfection of internal forms, but how these effects perfect the world. His discussion is eclectic, based on the views of Plato, Seneca, Aristotle, his commentators, and Thomas Aquinas.

Pomponazzi began by adhering to a position attributed to philosophers who follow Plato's Timaeus, which teaches that, because the universe was created by a perfect God, all of its contents must be perfect.

For there is nothing conceived in the world which does not give something to nature, and have its own utility in the universe, and should be of the greatest good with respect to its own kind. For God, according to the philosophers, is the greatest and wisest author, and since the universe is the work of God, therefore it is fitting that he made it most perfectly, as Plato puts it in the Timaeus. ${ }^{25}$

${ }^{23}$ For Pomponazzi's debts to medievals, see Chris Schabel, "Divine Foreknowledge: Auriol, Pomponazzi, and Luther on 'Scholastic Subtleties'," in The Medieval Heritage in Early Modern Metaphysics and Modal Theory, I400-I700, ed. Russell L. Friedman and Lauge O. Nielson (Dordrecht: Kluwer, 2003), I65-90. For Pomponazzi's alleged role in initiating modern science, see most recently: Stephen Gaukroger, The Emergence of a Scientific Culture (Oxford: Oxford University Press, 2006), I07-16.

${ }^{24}$ Pietro Pomponazzi, Dubitationes in quartum meteorologicorum (Venice: F. De Franceschi, I 563), 5or: Dicit enim philosophus quod homogenea ista, ut metallica, sunt minus nota quam organica: non quia sint in composito, vel extra compositum; sed quia minus habent de forma $\mathcal{E}$ p plus de materia: viciniora enim sunt materiae magis quam distantia a forma.

${ }^{25}$ Pomponazzi, In libros Meteororum, Biblioteca Ambrosiana MS R. 96 sup., 77v: Nulla enim res abstracta est in mundo quae non conveniat naturae ad aliquid, et propriam habeat utilitatem in universo, et in suo genere sit maxima bona: Deus enim secundum Philosophos est auctor optimus et sapientissimus, cum autem universum sit opus Dei, oportet ergo quod perfectissime hoc fecerit, ut Plato posuit in Thimeo. 
Having concluded that there are final causes for the winds and earthquakes, as there are for all natural things, Pomponazzi now must explain what they are. Seneca contended that winds are useful for purging the air of pestilential vapors, ${ }^{26}$ an idea that Pomponazzi believed to be confirmed by experience: closed rooms are less healthy than airy spaces. Moreover, winds bring rain clouds and farmers note that winds scatter seeds and cause grain to swell in size.

This analysis, however, does not end the discussion. What should be made of all of the harm that violent winds create? One solution is to consider them to be failures to reach an end; they are nature's mistakes, such as when a "writer errs, a physician kills." ${ }^{27}$ In Aristotle's eyes, natural goals are for the most part, but not always attained; nature's failure to reach perfection raises doubts. How is it that God created the winds for the greater good, but often they fail to assist that greater good and cause evil? God could not be ignorant that this happens. Averroes' solution, that these bad events occur by chance, and that only good things are known to God, is not satisfactory to Pomponazzi because it goes against Christian faith as well as Aristotle's words. A partial solution is found in the intrinsic perfection of the meteorological phenomena; citing (Pseudo-)Dionysius the Areopagite, who contended that good dogs should be furious ones, Pomponazzi argued that a good wind is one that is strong, lightning that does not strike anything is not worthy of being lightning, and earthquakes are only good with respect to their genus if they destroy cities and provinces. ${ }^{28}$

The destruction of cities and their inhabitants, however, might seem to be a clear evil, not necessarily part of the functioning of a perfect universe. Pomponazzi's solution is surprisingly theological: "For God is the cause of all things, except evil desires, of which we are the cause. But there are many things that seem bad to us, which are optimal, because we are ignorant of their purpose." ${ }^{29}$ Thus he argued that these destructive winds and earthquakes might seem bad, but we are not able to understand the true purpose for which God created them. Echoing Aristotle's position outlined in De generatione et corruptione 2.IO, that destruction is required for there to be perpetual generation and being, Pomponazzi gave examples that demonstrate the cyclical nature of destruction and death that in turn leads to generation. Many regions were required to become weak, in order for Rome to have become an empire; for someone to become rich, many around him must become poor. He even suggested that it might be good "should the Turk come,

${ }^{26}$ Seneca, Naturales quaestiones 6.I 8.I, trans. T. H. Corcoran, 2 vols. (Cambridge, MA: Harvard University Press, I97 I-I972).

${ }^{27}$ Pomponazzi, In libros Meteororum, $78 \mathrm{r}$ : scriptor errat, medicus interficit.

${ }^{28}$ Pomponazzi, In libros Meteororum, 79r-v: Unde Divus Dionisius in quarto cap. 4 de divinis nominibus, illi canes non sunt boni, qui non sunt furiosi, sic venti fortissimi sunt optimi in suo genere, et asinus qui est grossissimae naturae inter omnes asinos est optimus asinus. Valde venti Turbines non essent turbines nisi tales essent sicut sunt, unde relucet maximi Dei perfectio in illis, sicut et fulmen non esset fulmen, nisi operaretur ea, quae operatur: sic etiam terrae motus non esset terrae motus, nec bonus in suo genere nisi subverteret civitates et provincias. See Pseudo-Dionysius Areopagita, De divinis nominibus 4.25.

${ }^{29}$ Pomponazzi, In libros Meteororum, 8or: Deus enim est causa omnium rerum, excepta mala voluntate, huius enim nos causa sumus, multa enim nobis videntur mala, quae sunt optima, quoniam nos finem illorum ignoramus. 
because afterwards, we should be better Christians. ${ }^{\circ}{ }^{\circ}$ Conquest and humiliation could deepen faith.

Even though the belief in the unknowable nature of God's causes has its origins in theology, solace is to come not from Christianity, but from philosophy, in particular Stoic philosophy. A realization that floods, earthquakes, and whirlwinds can strike anywhere could lead to a sense of lack of security. Security, however, according to Seneca, comes from understanding that we are more secure when we admit that complete security does not exist anywhere. According to Pomponazzi, philosophers are those who are most secure because they

know that everything happens from the order of nature, and therefore they do not marvel at these effects as the unworthy vulgar do, since they recognize the causes of its effects and that it is orderly and best according to nature. Therefore they know the positioning and ordinatio of God. ${ }^{31}$

Thus Pomponazzi revealed the ethical goals of natural philosophy: first, eliminating wonder by explaining the causes of natural effects; and second, bringing further security through an understanding that God has ordered the world in the best way possible.

The first of these two goals was at the heart of his De incantationibus, a work in which he used hypothetical naturalistic explanations to suggest that wondrous and seemingly miraculous events could be explained by physical causes rather than demonic or angelic influences..$^{32}$ While some scholars have seen this earlier work as evidence of Pomponazzi's alleged heterodoxy, in the lectures on the Meteorology, he maintained naturalistic explanations while also asserting the existence of an omnipotent God who is the ultimate cause of a well-ordered universe. And although he appealed to Seneca's ethical justification for the practice of natural philosophy, Pomponazzi's acceptance of a well-ordered universe entails neither Stoic material determinism nor the belief that it is possible to know the causes for everything the universe holds. These positions locate Pomponazzi in a kind of middle ground, whereby he confirmed that the world was divinely ordered and that contemplation of this order instills wisdom, yet still held that the vision of a complete philosophical understanding of the world is the domain of fools.

The vain desire to know everything puts some philosophers in an unenviable position: "My Lord, it is no wonder if philosophers are mocked by common people, since they want to examine everything and what God can do ... they want to unite God's secrets and nature, therefore they spurn riches and pleasures." These philosophers, however, are mocked not just by common people but by Pomponazzi as well. His assault better identifies the strains of thought to which he objects, mainly Peripatetic proponents of astral determinism: "Peripatetics, however, and

${ }^{\circ}$ Pomponazzi, In libros Meteororum, 8or-v: Unde forsan esset bonum, quod Turca veniret, quoniam essemus, postea meliores christiani.

${ }^{31}$ Pomponazzi, In libros Meteororum, 8ov: Ideo Philosophi sunt securissimi, quoniam ipsi sciunt haec omnia ex ordinatione naturae evenire, ideo non mirantur de illis effectibus, ut facit ignobilis vulgus; quoniam horum effectuum causas cognoscunt; et ita esse ordinatum optime a natura, Ideo sciunt se positam et ordinationem Dei.

${ }^{32}$ Pietro Pomponazzi, De naturalium effectuum causis sive de incantationibus (Basel: H. Petri, I 567). 
other stupid philosophers, who want to know everything, say that this [cyclical destruction and regeneration] happens out of the necessity of the heavens." Accordingly, theologians offer a more attractive solution that admits the limits of human knowledge: "Therefore those religiosi do it well and better, who respond securely, that because the will of God wishes it such, thus it becomes such; therefore, no other cause of these things must be sought out." ${ }^{33}$ While Pomponazzi's critique of "stupid philosophers" and praise of religious figures who wish to leave such questions behind might at first sight appear ironic, the rest of the text supports a literal reading of his assessment of these views.

Pomponazzi repeatedly praised theologians for their side-stepping of difficult questions. For example, Pomponazzi admitted that he failed to find an adequate interpretation to Aristotle's obscure claim that sea water rests in the natural place of water, but not the natural place of the sea, and that this displacement is the cause of the unending motions of the sea. He wrote, to those who might declare "nature to be stupid" because it sets up impediments to the sea's resting in its natural place, that "I say that it did this because it is better, that is the good of the universe, that later there is greater perfection ... or it is better thus, as our theologians say well: 'Everything which happens, God made in the heaven and the sky.'"34 Furthermore, he reiterated his critique of those who uphold a deterministic view of the universe based on the motions of the heavens. The words of philosophers and astrologers are simply not true: "Philosophers and Astrologers can save this in some way, although their words are not true, but it could be caused from the celestial bodies and the motion of the stars." 35

Pomponazzi's rejection of determinism, however, does not resist further scrutiny. This scrutiny is merited by Aristotle's failure to discuss final causes in the Meteorology, a fact that Pomponazzi used as the basis for the final question on Meteorology 3. This dubitatio does not address directly any specific meteorological effect, but rather a number of those discussed in this book, including rainbows, haloes around the sun, and mock suns caused by alterations of the sun's light, or as Pomponazzi puts it, "refraction." His questioning stems from tensions in Aristotle's writings. On the one hand, Aristotle argued that some aspects of natural beings come to be not according to an end, but out of material necessity; Pomponazzi gives two examples-that infants are born unable to walk and that humans have

${ }_{33}$ Pomponazzi, In libros Meteororum, 54r-v: Profecto, Domini mei, non est mirum si Philosophi irridentur a vulgaribus, quoniam volunt omnia scrutari, et quid possit Deus, quoniam non grosso modo intendunt in via populari, sed volunt secreta Dei uniari, et naturae, Ideo spernunt divitias et voluptates: exemplo fuit concivis noster Petrus de Mantua, qui mortuus est in Hospitali, unde altiora re ne quaesiveris. Ideo bene et melius faciunt isti Religiosi, qui securius respondent, quoniam voluntas Dei sic vult, ideo sic fit, Ideo non est alia illorum quaerenda causa. Peripathetici autem et alii stulti Philosophi qui volunt omnia scire, dicunt ex necessitate motus Coeli haec evenire, quoniam necesse est omnia quae sunt genita aliquando interire, et alia rursum gigni.

${ }^{34}$ Pomponazzi, In libros Meteororum, 57r: Dico quod hoc fecit propter melius scilicet bonum universi, quod postea est maior perfectio . . . aut quia sic placuit, ut bene dicunt Theologi nostri, Omnia enim quae volunt Deus fecit in Coelo, et in terra.

${ }^{35}$ Pomponazzi, In libros Meteororum, $8 \mathrm{Ir}$ : Philosophi tamen possunt et Astrologi hoc salvare alio modo licet dicta sua non sint vera, nam hoc potest esse ex corporibus coelistibus, et ex causa motus syderum. Cf. Franco Graiff, "I prodigi e l'astrologia nei commenti di Pietro Pomponazzi al De caelo, alla Meteora e al De generatione," Medioevo 2 (I976): 33 I-6I. 
armpit hair-that demonstrate nature's failures. ${ }^{36}$ On the other hand, nature does nothing in vain. Do these rare effects, such as haloes and parhelia, Pomponazzi asks, happen purely by chance, caused by the disposition of matter, or does nature intend them, endowing them with an external end?

The argument that these effects are the result of chance is based on his reading of De generatione et corruption 2.I0 and Physics 8, from which Pomponazzi contended that the purpose of the motions of the celestial bodies is to create generation and corruption in the sublunary region. Rainbows, mock suns, and "rods" are connected to the heavenly motions but are evidently unrelated to the processes of generation and corruption; they occur "because the sun moves thus and finds such matter disposed, therefore it acts by necessity." This material necessity means that "it is not done with intent, but just as when it rains 'under the Dog' [i.e., when Sirius appears, or midsummer], that is by chance." Thus these effects are the result of chance and have no "understandable purpose" (rationabile fines). Moreover, the extreme rarity of the events-rainbows are rare, but mock suns and rods even more infrequent-adds to the argument that they occur by pure chance and by material necessity. ${ }^{37}$

Pomponazzi, however, was not satisfied that this argument was conclusive. The opposing opinion is based on a multiplicity of positions, the first of which argues that because "nature does nothing in vain, these effects are natural, therefore they do not come into being in vain. ${ }^{38}$ Additionally, according to the Prior Analytics and Metaphysics, what is determined per se must occur always or for the most part. Given that these events, while rare, always occur when the light of the sun is refracted in the correct way, it appears that these happen not by chance. Moreover, that Aristotle's explanation of these effects is mathematical, the most certain form of demonstration, suggests that they are not random..$^{39}$ And while they are rare with respect to time (in ordine tempus) they are not so with respect to their cause (in ordine ad suam causam). This distinction is parallel to eclipses, which are rare but

${ }^{36}$ Pomponazzi, In libros Meteororum, IO7v: Primo modo tunc sunt per se intenta, secundo modo non sunt per se intenta: nam quod sint duo oculi duo nares haec omnia habent suum finem, sed quod homo nascatur claudus, aut quod sint pili sub ascellis, illa magis videntur nocere, quam prodesse, ideo dicuntur esse ex necessitate materiae.

${ }^{37}$ Pomponazzi, In libros Meteororum, I07v: Et haec quaestio satis difficilis est nam primo quod fiant ex necessitate materiae, et non propter finem, quoniam ex secundo de generatione et octo physicorum se motu solis et astrorum generationes et corruptiones fiunt in istis inferioribus, nam isti effectus refractorum sunt coniuncti aliis affectibus, nam quia sol sic movetur, et invenit talem materiam sic dispositam ideo necessario agit, ideo non videtur, quod hoc sit factum ex intentione, sed sicut quando pluit sub cane, quod casuale est, sic videtur etiam dicendum de istis, fit enim in pauciori, nam rarissimi fiunt illae refractiones, cum raro videamus iridem, rarius autem parelias et virgas.

${ }^{38}$ Pomponazzi, In libros Meteororum, I08r: natura nihil facit frustra. Sed illis sunt effectus naturales ergo non fiunt frustra.

${ }^{39}$ Pomponazzi, In libros Meteororum, I08r: Ad aliam partem, quod sint per se intenta a natura, quoniam habemus in fine tertii de anima, in libro de animalibus in libro de partibus et mille aliis in locis, quod natura nihil facit frustra. Sed illis sunt effectus naturales ergo non funt frustra. Item primo posteriorum [Analytics] et primo meth. [i.e., the Metaphysics] ea quae sunt per se sunt determinata, et debent fieri semper aut frequenter, sed illi effectus funt semper aut frequenter, casus autem funt extra semper, aut frequenter, ergo ista non sunt casualia, quod autem illi sint effectus per se, patet nam Aristoteles vult se probasse effectus istos demonstratione, et mathematice, ideo certissime ergo amplius in primo posterior ubi dicit eorum quae saepe fiunt sunt demonstrabiles. 
regular: "never is the earth in between the sun and the moon, so that an eclipse should not follow." 40

The solution to this impasse is a clarification of what chance means. Thomas Aquinas's attack on Avicenna's assertion that spontaneous generation of wasps out of excrement occurs purely accidentally offers a way forward. ${ }^{4 \mathrm{I}}$ Spontaneous generation is accidental or chance in respect to who or what defecated, but not in respect to its own causes. Pomponazzi added that while excrement itself is not a product designed by nature per se, nevertheless nature utilizes it for good: "Although we throw out dung, farmers collect it." 42

Anticipating objections, he cited Averroes' contention that conjunctions of events happen out of pure chance, having no purpose at all. ${ }^{43}$ By conjunction, he here means what Aristotle labeled that which happens according to "luck" (tuchē). Events are "lucky" when two unrelated events coincide, creating the appearance of intent when in fact there was none. The example from the Physics is the man who runs into someone useful while at the market. Having met this person, it was as if they had made an appointment and his purpose of going to the agora was fulfilled, whereas in truth he had gone to the market for another reason. ${ }^{44}$ Averroes thought that this meant that pure chance existed, and that, in the words of Pomponazzi, "what was written in the law of Mohammed was false, that everything that happens, happens by necessity. Rather, neither God nor anyone, through God understood this." 45 Pomponazzi, however, dismissed Averroes' conclusion, aligning himself with Thomas and asserting God's omniscience:

But you should note that $\mathrm{D}$. Thomas and others say that this conjunction does not have a cause, although God puts it, since he sees everything, and this that $\mathrm{S}$. Thomas says is most true, since nothing is simply by chance, since everything is known by God, and God has known and determined causes, even though according to nature this is by chance. ${ }^{46}$

${ }^{4}$ Pomponazzi, In libros Meteororum, I08r: Ibi omnes expositores dicunt quod sed illa raro fiant in ordine ad tempus. Tamen in ordine ad suam causam saepe, imo semper fiunt, nam numquam causa est disposita quin semper fiat aut sequatur effectus, nam numquam sit interpositio terrae inter solem et lunam, quin sequatur eclipsis.

${ }^{4 \mathrm{r}}$ For this debate, see Dag Nikolaus Hasse, "Spontaneous Generation and the Ontology of Forms in Greek, Arabic and Medieval Latin Sources," in Classical Arabic Philosophy: Sources and Reception, ed. Peter Adamson (London: Warburg Institute, 2007), I 50-75.

${ }^{42}$ Pomponazzi, In libros Meteororum, I08v: Excrementa licet per se non sint intenta a natura, tamen natura utitur eis ad aliquod bonum, nam nos reiicimus stercora, et rustici colligunt ea.

${ }^{43} \mathrm{On}$ Averroes and chance, see Catarina Belo, Chance and Determinism in Avicenna and Averroes (Leiden: Brill, 2007), I 2 I-48.

${ }^{44}$ Aristotle, Physics 2.4.I95b36-I96a5.

${ }_{45}^{45}$ Pomponazzi, In libros Meteororum, Io9r: et ideo dicit Averroes quod falsum est, quod scribitur in lege Maumethi, quod omnia quae habent evenire necessario eveniant; nam nec Deus, nec alius propter Deum hoc cognovit.

${ }^{46}$ Pomponazzi, In libros Meteororum, I09r: Aliae enim omnia quae accidunt de necessitate evenirent. Non eveniunt autem illa de necessitate, sed a casu, et ideo dicit Averroes quod falsum est, quod scribitur in lege Maumethi, quod omnia quae habent evenire necessario eveniant; nam nec Deus, nec alius propter Deum hoc cognovit. Sed notetis quod D. Thomas et alii dicunt, quod illa coniunctio non habet causam, tamen Deus hoc ponit, quoniam videt omnia: et hoc quod dicit S. Thomas est verissimum, quoniam nihil est simpliciter casuale, quoniam omnia sunt Deo nota, et causas habet Deus notas et determinatas, sed naturaliter hoc est casuale. For Thomas' rejection of chance as a cause, see Summa theologiae I, q. I03, a.I. 
272 JOURNAL OF THE HISTORY OF PHILOSOPHY $48: 3$ JULY 2 OIO

Pomponazzi distinguished between God's knowledge, which is perfect, and nature, which is imperfect and at times accidental. Attempts to understand these seemingly chance events by looking at nature are fruitless. ${ }^{47}$

Pomponazzi thus concluded, agreeing with Thomas, that God determines everything, while still maintaining that there are chance events, at least according to nature. As a result, events that occur by coincidence support the theologians who say that we cannot know all of God's purposes. Philosophy has self-recognized limits that can only be transcended by faith:

These are said by Theology and said well, but are not according to Aristotle's mind. Much more should be believed [credenda] here than investigated, but stupid philosophers wish to investigate everything. Aristotle wishes that the conjunction have no cause, and that which these men [i.e., the stupid philosophers] say is neither Peripatetic nor Academic. $4^{8}$

Efforts to increase the understanding of final causes in nature are unproductive because according to nature, coincidences do not have final causes. Only religious faith allows for the understanding that these purposes exist.

Not everyone was persuaded, however, that all meteorological effects possess some deeper purpose. Agostino Galesi, a professor at Bologna, writing in I 57 I during a crisis caused by a series of earthquakes in Ferrara, pointed to the ongoing controversy over the teleology of such destructive events. In a work dedicated to the Cardinal of Bologna, Gabriele Paleotti, he dismissed the assertions that earthquakes are part of the natural order that brings about the perfection of the universe:

What then can be considered the perfection of such things, when they either portend evils or bring about these great calamities to men? Then truly, what is that perfection? Since in no way do they confer any order, or beauty, or utility to the universe, but rather they disrupt everything, strip away beauty, and demolish. ${ }^{49}$

Galesi's tone evokes the urgency and despair felt in the aftermath of this disaster, yet does not betray nihilism so much as reflects actual disputations that had taken place in Bologna, where he had earned his doctorate in arts and medicine and, by I $57 \mathrm{I}$, had become a professor of philosophy..$^{\circ}$

Lodovico Boccadiferro, also a professor of philosophy at Bologna, but a generation before Galesi, followed his teacher Pomponazzi, but only up to a point.

${ }^{47}$ For Pomponazzi's pessimism toward the possibility of complete knowledge of the natural world, see Stefano Perfetti, "Docebo vos dubitare. Il commento inedito di Pietro Pomponazzi al De partibus animalium (Bologna I 52 I-24)," Documenti e Studi sulla Tradizione Filosofica Medievale Io (I999): 439-66.

${ }^{4}$ Pomponazzi, In libros Meteororum, Io9r: Haec autem dicta sunt Theologia et bene dicta, sed non sunt ad mentem Aristotelis. Multa autem hic magis credenda sunt, quam investiganda, sed stulti Philosophi velint omnia investigare. Aristoteles enim vult quod illa coniunctio nullam habeat causam, et ideo illud quod dicunt isti viri non est Peripateticum nec Accademicum.

${ }^{49}$ Agostino Galesi, De terraemotu liber (Bologna: A. Bennaci, I 57I), 69: Quae denique talium rerum configi potest perfectio, cum aut mala portendunt, aut magna hominum calamitate, illa secum afferunt? iam vero, quae tandem est ista perfectio? Cum non modo quicquam ad universi aut ordinem, aut ornatum, aut utilitatem (quae tres dotes mundum praecipue muniunt) conferat, sed potius omnia perturbet, decore exuat, atque demoliatur.

${ }^{5} \mathrm{O}$ On the details of Galesi's academic career, see David A. Lines, "Science and Universities of Early Modern Europe: Teaching, Specialization, Professionalization," Early Science and Medicine 6 (200I): $267-323$, at 3 I 6 . 
He believed that the imperfect nature of meteorological phenomena means that we are ignorant of their final causes, even if such causes exist..$^{5 \mathrm{I}}$ His view, however, still allows for the possible existence of final causes. In his commentary on the second book of the Meteorology, which was published posthumously in I 570, a year before Galesi's earthquake treatise and the actual year the tremors began to strike the Po Valley, the aptly named Boccadiferro used Aristotle's failure to identify final causes for meteorology as a starting point for a prolix discussion. For some meteorological phenomena his reasoning was similar to Pomponazzi's: that their ultimate purpose was for the generation of being that accompanied the perfection of the universe..$^{52}$ In the case of earthquakes, however, he was less sure:

\begin{abstract}
About the final cause I say that either the earthquake does not have a final cause, this effect arises out of the necessity of matter, it is neither an intention of the exhalation, nor does it intend this motion, but is according to the ascent [of the exhalation], or if it has an end, the end of the generation of the earthquake is because this motion of the smoky exhalation provides for that the realization of generated things, that is, the perfection of the universe..$^{53}$
\end{abstract}

While Boccadiferro gives a possible final cause, he also admitted that earthquakes might just be accidental effects caused purely from the "necessity of matter" lacking a purpose or utility to humankind or the functioning of the world.

4 .

One line of Aristotelian thought emphasized the limitations of meteorological knowledge, Lutherans, however, largely adopted a contrary approach and saw meteorological phenomena as knowable signs of God's providence or anger. In a reworking of Aristotelian concepts of teleology, meteorology's final causes were found not only in the necessary links between benign weather and human welfare, but also in the portentous nature of rare and violent events. Meteorological signs were seen as prophetic, and their purpose was found in their ability to foreshadow the future. This view is reminiscent of Seneca's description of the Etruscans, a race famous as proponents of divination in antiquity: "they are of the opinion that things do not reveal the future because they have occurred, but that they occur because they are meant to reveal the future." ${ }^{4}$

${ }_{5}^{5}$ Lodovico Boccadiferro, Lectiones super primum librum Meteorologicorum Aristotelis (Venice: G. Scoto, I 590), 3: Dico ulterius, quod licet multae sint impressiones quarum ignoraviumus finem: tamen bene de eis potest haberi scientia, cum habeant veras, firmas determinatas causas: quibus positis, de necessitate sequitur effectus ille.

${ }^{52}$ Lodovico Boccadiferro, Lectiones in secundum, ac tertium Meteororum Aristotelis libros [Lectiones in secundum ac tertium Meteororum] (Venice: G. Scoto, I 570), 33 r: Ultima dubitatio de causa finali quam omittit Aristo. quid ergo finis cur non expressit super, dico ex libris physicorum, quia duplex finis generationis, $\mathcal{G}$ rei generatae, finis generationis est forma rei generatae, finis rei generatae perfectio universi, finis ergo generationis est exhalationis finis rei generatae est perfectio universi.

${ }_{53}$ Boccadiferro, Lectiones in secundum ac tertium Meteororum, 38v: De causa finali dico quod aut terremotus non habet causam finalem, fit ex necessitate materiae iste effectus, non est intentus exhalatio non intendit istum motum, sed secundum ascendentem, aut si habet finem, finis generationis motus terrae, quia permet fumidae exhalationis acquiritur iste motus finis rei generatae, est perfectio universi.

${ }^{54}$ Seneca, Naturales quaestiones 2.32. 
From antiquity through the Renaissance, many believed rare meteorological events to be portents. The belief that comets, earthquakes, or rains of frogs or wool presaged plagues, famines, or the death of rulers ran through both learned and folk traditions. Aristotle's writings formed a foundation for the idea of natural signs, even if the direction of his argument is ambiguous. Aristotle adduced that comets, which he believed to be meteorological, were instances of irruptions of the fiery exhalation in the upper air, based on an argument that utilized signs. He contended that an indication that this is probably the case is found in the fact that frequently the appearance of comets is followed by a dry and windy period. The dryness is directly caused by the comet's burning. Thus Aristotle gave a potential rationale for using comets as predictors, or natural signs of droughts, famines, and storms because they initiated a concatenation of physical influences. ${ }^{55}$

The belief that some sublunary phenomena could predict disasters went beyond Aristotle's modest statements found in his extant writings. His description of a recent comet (373-372 BC), "the great comet which appeared at the time of the earthquake in Achaea and the tidal wave," suggests that his contemporaries thought the coincidence was defining if not causally related. ${ }^{56}$ Furthermore, apparent correspondences between the arrival of comets and the deaths of rulers provided empirical evidence of the ominous nature of comets in both antiquity and the Middle Ages. Most famously a comet coincided with the Battle of Hastings, as the Bayeux tapestry depicts. But lesser known examples fill the pages of medieval chronicles and the writings of ancient historians..$^{57}$

During the Middle Ages, the meaning of these portents was inevitably intertwined with Christian understandings of history and the future. While comets or rare weather events might be causally related to other disasters, they were also seen as divine signs that could portend the end of the world. Some theologians, philosophers, and portions of the general public understood them as supernatural deviations from the order of the universe, and thus as evidence of God's will. Earthquakes, the raining of animals, and plagues, which were widely believed to be caused by diseased air, were all interpreted as signs of the coming Apocalypse during the late Middle Ages. ${ }^{5}$ Moreover, the Catholic Church maintained that destructive weather was the result of divine punishment throughout the sixteenth century, as Papal authorities absolved communities that had suffered from crops damaged by drought or hail..$^{59}$ By the I 520 , however, this semiotic understand-

${ }^{55}$ Aristotle, Meteorologica I.7.344bI9-345a5, trans. H. D. P. Lee (Cambridge MA: Harvard University Press, I952).

${ }^{56}$ Aristotle, Meteorologica $\mathrm{I} .6 .343 \mathrm{~b} 2-3$.

${ }^{57}$ Sara Schechner Genuth, Comets, Popular Culture, and the Birth of Modern Cosmology [Comets] (Princeton: Princeton University Press, I997), I7-50.

${ }^{5}$ Laura A. Smoller, "Of Earthquakes, Hail, Frogs, and Geography: Plague and the Investigation of the Apocalypse in the Later Middle Ages," in Last Things: Eschatology and Apocalypse in the Middle Ages, ed. Paul Freedman and Caroline Bynum (Philadelphia: University of Pennsylvania Press, 2000), I $56-87$.

${ }^{59}$ For example, see Carlo Ginzburg, The Night Battles: Witchcraft $\mathcal{E}$ Agrarian Cults in the Sixteenth and Seventeenth Centuries, trans. A. Tedeschi and J. Tedeschi (Baltimore, MD: The Johns Hopkins University Press, I992), 23. 
ing of marvels became key to many Lutherans, who believed that the purportedly increasing number of prodigies, meteorological or otherwise, was intimately tied to "the apocalyptic belief that this state of disorder had reached a crisis, and that resolution was imminent or already begun." 60

Luther's own consideration of weather emphasized the portentous. His decision to enter the Augustinian order allegedly followed his being nearly struck by a bolt of lightning, which, according to his own account, he interpreted as a sign meaning that he should become a friar. ${ }^{61}$ Later, after the Reformation had begun, Luther's sermons on Luke 2 I, typically given just before the solstice, which was creeping into early December because of the inaccuracy of the Julian calendar, addressed the signs of apocalypse. This verse says that before the second coming there will be disasters such as earthquakes, famines, and plagues, as well as "awesome sights and signs in the sky." Luther contended that recent eclipses, falling stars, comets, rainbows, bloody suns, multiple suns, and other celestial events were signs. He wrote that "since the beginning of time there had never been so many rainbows and eclipses." ${ }^{62}$ The supposedly growing number of such events beckoned the end of times. Moreover, in the Table Talks, we also find that Luther considered meteorological phenomena as having supernatural significance. For example, it is reported that Luther described a winter-time thunder clap, categorized as a chasm, as being a sign of Satan. He also interpreted "fruitful weather" as proof of God's love for humanity. ${ }^{63}$ Thus, in the Sermons on Luke 2I, while rare events were ominous or apocalyptic, fair weather might signal God's protection.

The meteorological writings composed by Luther's followers reflected his interest in the prodigious and portentous. Well into the seventeenth century, Lutheran sermons on Luke $2 \mathrm{I}$ and numerous pamphlets contended that observable features of the sun, moon, and stars in addition to wondrous events were signs of a worldending flood. ${ }^{64}$ Phillip Melanchthon, a colleague and follower of Luther, combined Luther's desire to find signs in rare meteorological events with a vision of natural philosophy that emphasized providence and divine order. His teachings on natural philosophy are contained in his work Initia doctrinae physicae (first published in I 549), which served as both a model for future Aristotelian "text-books," as well as an introduction to natural philosophy for his students at Wittenberg and other German universities, especially Leipzig. ${ }^{65}$ Following Plato, Melanchthon believed

${ }^{60}$ Robin Bruce Barnes, Prophecy and Gnosis: Apocalypticism in the Wake of the Lutheran Reformation (Stanford, CA: Stanford University Press, I988), 58.

${ }^{61}$ Otto Scheel, ed., Dokumente zu Luthers Entwicklung (bis I 5 I9), 2nd ed., (Tübingen: J. C. B. Mohr, I929), I 5 I

${ }^{62}$ Martin Luther, D. Martin Luthers Werke kritische Gesamtausgabe (Weimar: H. Böhlau, I883- ), $45: 338,29: 62$ I-22, II:207, 32:228-29, 37:6I 6.

${ }^{63}$ Martin Luther, D. Martin Luthers Werke: Tischreden (Weimar: H. Böhlau, I883- ), 3:364-65, $4: 365-66$

${ }^{64}$ Volker Leppin, Antichrist und Jüngster Tag: Flugschriften: das Profil apokalyptischer Flugschriftenpublizistik im deutschen Luthertum I 548-I6 I 8 (Gütersloh: Gütersloher, I999), 87-96.

${ }^{65}$ For Melanchthon and the development of Aristotelian "text-books" in the sixteenth century, see Charles B. Schmitt, "The Rise of the Philosophical Textbook," in The Cambridge History of Renaissance Philosophy, ed. Charles B. Schmitt et al. (Cambridge: Cambridge University Press, I988), 792-804; Patricia Reif, "The Textbook Tradition in Natural Philosophy," Journal of the History of Ideas 30 ( I969): I7-32. 
that the universe was an essentially orderly creation of the divine mind of God. While admitting the impossibility of examining everything, Melanchthon, unlike his contemporaries in Italy, believed that certitude about the natural world was possible and that natural philosophy should work in a method that will provide the truth.${ }^{66}$ Knowledge about nature, therefore, should be an aid in understanding God's plan, which runs in accordance with determined laws of nature ${ }^{67}$

A key source for Melanchthon's consideration of providence and the upper regions was the humanist Giovanni Gioviano Pontano's astronomical and meteorological verse written in the I470s and revised in the I490s, even though these poems are not philosophical in their orientation and comment on causation or explanation only in an oblique manner. Melanchthon praised Pontano's Meteora for its elegance, far removed from what he considered to be the barbaric style of scholastic authors, and for his dependence on things rather than disputation. ${ }^{68}$ Pontano's Meteora retained some aspects of Aristotelian meteorology, such as the dual exhalations, but its focus was on correspondences between meteorological events and human tragedies. Using the Greek gods as a motif, Pontano linked changes in the weather to wars, famines, overthrows of governments, and mysterious destructions of livestock. ${ }^{69}$ Explorations of such links, under the encouragement of Melanchthon, became standard for sixteenth-century Protestant meteorological treatises.

Pliny the Elder's Natural History also played an influential role in the teaching of meteorology at Wittenberg. Because Melanchthon had written a paraphrase of the prefatory chapter of the Natural History, a work that was concerned with the prodigious and marvelous, as well as with causation, there were rumors that he had also written the commentary on the second book of the Natural History, which was printed under the name of Jakob Milich. ${ }^{\circ}$ While these rumors were probably false, Milich was close to Melanchthon, and taught Pliny's work, which discusses astronomy and meteorology, in Wittenberg as early as I 534 . Milich believed Pliny's work to be an ideal introduction to these areas of knowledge because of its completeness and its author's knowledge of ancient sources and his native Latin. ${ }^{71}$ Although Milich

${ }^{66}$ Phillip Melanchthon, Initia doctrinae physicae (Wittenberg: P. Seitz, I 553), 22r: Quare teneamus quod verissimum est, esse multarum rerum in natura veram $\mathcal{E}$ certam cognitionem, etiamsi non omnia pervestigari possunt. Haec cum supra dicta sint de certitudine, nunc sum brevior, etsi tantum ideo de modo procedendi disseritur, ut certitudo quaeratur.

${ }^{67}$ Charlotte Methuen, Kepler's Tübingen: Stimulus to a Theological Mathematics [Kepler's Tübingen] (Aldershot: Ashgate, I998), 90-9I.

${ }^{68}$ Sachiko Kusukawa, The Transformation of Natural Philosophy: The Case of Philip Melanchthon (Cambridge: Cambridge University Press, I995), I32.

${ }^{69}$ G. Pontano, I poemi astrologici, ed. M. de Nichilo (Bari: Dedalo, I975).

${ }^{7 \circ}$ Charles G. Nauert, Jr., "Caius Plinius Secundus," in Catalogus translationum et commentariorum, vol. 4, ed. F. Edward Cranz (Washington, D.C.: Catholic University of America Press, I980), 384.

${ }^{71} J a k o b$ Milich, Liber II. C. Plinii de mundi historia, cum commentariis [De mundi historia, cum commentariis] (Frankfurt: P. Brubach, I 543), gr: Nihil autem opus est me de Plinii laudibus dicere, qui non tam librum, quam bibliothecam, nobis reliquit, complexus uno volumine fere totam rerum naturam: ut ne apud Graecos quidem extet unus aliquis locupletior autor. Adhaec, conservavit multis de rebus lectissimas doctorum sententias, item Latinas appellationes plantarum. 
found deficiencies in Aristotle's astronomy, ${ }^{72}$ for natural philosophy he believed that Peripatetic explanations were superior. ${ }^{73}$ Thus his treatment of meteorology retained the terminology of imperfect mixtures and discussed the subject in terms of the four traditional kinds of causation.

Milich's discussion of final causes was cautious, although he made a clear attempt to distinguish his views from those of the Epicureans, contending that nature's "ends result from a mind governing all of nature," and echoing the view of Lutheran theologians who equated the denial of providence with Epicureanism. ${ }^{74}$ In Milich's view the physicus should be concerned with the ends that surround matter, meaning primarily forecasting how "these impressions signify some change in the air, serene weather, or a storm." 75 Therefore, in his discussion of comets, he explained that comets affect the world through physical causes. They "do not signify so much but affect." ${ }^{16}$ Nevertheless, after listing recent corresponding appearances of comets to historical events, he conceded that observation through the ages shows that comets have warned of worrisome events, and that "this sign can correctly be considered a final cause." 77 As a result, Milich included signs as part of the final causes of the natural world.

A similar approach to meteorology can be found in the meteorological writings of Marcus Frytsche, first printed in I 555 . Concerns with prodigies and their purpose are paramount in his work, which was reprinted in Wittenberg in $\mathrm{I} 58 \mathrm{I}$, I 583 , and I 598 . Included with the first and second editions, although not in subsequent ones, was a catalogue of strange events or prodigies coupled with a list of major historical events, thereby allowing readers to connect these events to past turning points since the founding of the first city, which he believed happened I657 years after the creation of the earth. In the sections of his Meteora dedicated to the ends of meteorology, he contended that meteorological events are not accidents, but signs. They are signs in the sense of being prodigious, both portents of future events and clues to divine providence. For example, he divided rains into

${ }^{72}$ Milich, De mundi historia, cum commentariis, 7r: Quare elegimus hunc librum Plinii, qui quasi in compendium contraxit praecipuos locos universae Physices: inclusit enim breviter in hunc unum libellum multa Aristotelis Volumina, librum de coelo, $\mu \in \tau \epsilon \epsilon \rho \alpha$, de mundo, addit Ẽ plaeraque Astronomia, necessaria in tali opere, quae tamen non attingit Aristoteleles, credo quod Graecis nondum satis noti essent planetarum motus.

${ }^{73}$ Milich, De mundi historia, cum commentariis, 84v: Hanc Epicuri sententiam secutus hoc loco Plinius coniungit atque commiscet impressiones in aere factas, cum apparentiis coelestibus, sed ita tamen, ut prudens lector facile vera a falsis discernere possit praesertim si mediocriter in philosophia Peripatetica versatus fuerit, quae in his naturalibus disputationibus longe vincit reliquas.

${ }^{74}$ Milich, De mundi historia, cum commentariis, 86r: Quia vero universa in hac natura destinata sunt ad certos fines, ergo necesse est ut hi fines pendeant ab aliqua mente gubernante hanc totam naturam. Robert D. Preus, The Theology of Post-Reformation Lutheranism [Theology of Post-Reformation] (St. Louis, MO: Concordia, I970), 2:196.

${ }^{75}$ Milich, De mundi historia, cum commentariis, 86r: Physicus autem quia tantum caussas in materia quaerit, itaque et fines tantum circa materiam quaerit, videlicet omnes istas impressiones significare aliquam aeris mutationem vel serenitatem vel tempestatem etc.

${ }^{76}$ Milich, De mundi historia, cum commentariis, 93v: Hactenus de physicis effectibus Cometarum dixi, de tempestatibus $\mathcal{E}$ aeris viciis. Haec non significat tantum sed efficit.

${ }_{77}$ Milich, De mundi historia, cum commentariis, $95 \mathrm{r}$ : Cum igitur omnium aetatum observatione compertum sit, Cometas minari tristes eventus, recte in caussa finali haec significatio recensetur. 
two kinds, the prodigious and the natural, just as Pliny had. Prodigious rains are when worms, frogs, fish, milk, hair, rocks, flesh, blood, or iron fall from the sky, as was supposedly witnessed by ancient Roman historians and naturalists. While they can be explained by natural explanations, such as rising viscous exhalations or the imperfection of parts of earth or mud, these causes are incomplete because "these are fatal and miraculous rains . . that can be called portents." ${ }^{8}$ Natural rains, however, are also signs of the divine, being "rivers of divine providence" that God creates to ensure the survival of plants by moistening the earth "almost like a clypsedra." 79

For Frytsche, teleology is linked to the larger significance of meteorological phenomena. The final causes of comets are their prodigious meaning. They are portents for "droughts, plagues, famines, wars, and changes in Kings, governments, and laws." ${ }^{\circ \circ}$ Their purpose is bipartite, either pertaining to the temporal needs of humans or reflective of God's particular desires. For example, the rainbow has two final causes; the first, which he calls physical, allows us to predict rain. The second is theological and signifies that God will not bring another Diluvium because the rainbow is a sign of the pact between humans and God. More ominously, earthquakes are a sign of God's vindictive nature and his desire to punish human sins. ${ }^{81}$

Johannes Garcaeus, a professor at Wittenberg, wrote about meteorology in a similar light in his 1584 Meteorologia. Arguing against what he considered a Stoic position that there are secondary causes that govern the natural world, Garcaeus emphasized God's will as the direct cause of meteorological events. God's complete freedom means that we cannot fully understand all of the physical causes of weather; God is incomprehensible and infinite. Nevertheless, according to custom and his usual way of ruling of the universe, God gives "warnings of unusual and singular events." ${ }^{22}$ Thus, Garcaeus equated final causes with a mind (mens) that governs nature and signals its intents through prodigies. The existence of a moderating and governing God eliminates the possibility of randomness and chance events, as the Epicureans maintained. Therefore, if meteorological events do not

\footnotetext{
${ }^{78}$ Marcus Frytsche, Meteorum, hoc est Impressionm aerearum et mirabilium naturae operum [Meteorum] (Nuremberg: J. Montanus, I 555), 25v: Prodigiosa pluvia dicitur, quando cum pluvia aliquando decidunt vermes, ranae, pisces, lac, pili. Item cum pluisse lapidibus, carne, sanguine, ferro $\mathcal{E}^{\circ}$ aliis rebus apud historicos legitur. Quarum rerum potest quidem naturalis ratio assignari, sed non adeo inexpugnabilis. Nam eas esse fatales

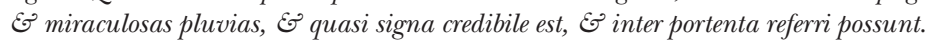

${ }^{79}$ Frytsche, Meteorum, 3 or: Est enim pluvia ut flumen divinae providentiae, qua providet Deus vegetabilibus, ut moderate humectentur, $\mathcal{E}^{\mathcal{O}}$ quasi clepsidra irrigentur, aqua guttatim e summo labente.

${ }^{8}{ }^{\circ}$ Frytsche, Meteorum, $93 \mathrm{r}$ : Finis Cometarum est parare siccitatem, pestem, famem, bella mutationem regnorum Eं Rerumpub. legum, traditionum.

${ }^{8}$ Frytsche, Meteorum, I $20 r$, I 47r.

${ }^{82}$ Johannes Garcaeus, Meteorologia (Wittenberg, I 584), 7r: Possuntne omnium Meteorum monstrari causae Physicae? Non. Affirmat enim sacra scriptura, multa oriri a prima causa rectrice $\mathcal{E} \mathcal{F}_{\text {moderatrice universae }}$ naturae incompraehensibili $\mathcal{E}^{2}$ infinita, praeter consuetum $\mathcal{E}$ solitum modum, quae liberrima voluntate sine connexione stoica secundarum causarum, multa perficit, movet exacuit, reprimit, compescit, mutat $\mathcal{E} \sigma$ excitat, quae insolitorum $\mathcal{E}$ ₹ singularium casuum sunt praenuncia.
} 
occur by the necessity of material causes and do not occur by chance, they must have meaning; their purpose being, in part, that they are signs of future events. ${ }^{83}$

Just as Frytsche had, Garcaeus defined the purpose of meteorology by dividing final causes into physical ones and theological ones. The physical final causes reveal the serenity of the weather and its utility in anthropocentric terms. He wrote, "There is nothing in meteorology that does not have either a manifest or hidden utility." The theological final causes are premonitions about future evils that will affect the earth. ${ }^{84}$ Against Epicurean calls for tranquility based on the absence of active gods and the presence of natural atomistic causes of dangerous meteorological events, he contended that lightning, blizzards, and earthquakes have their utility in provoking the fear of God and leading people toward a pious life. Reading this, the example of Luther's decision to enter the Augustinian order might very well have been in the minds of Lutheran readers. In any case, according to Garcaeus, meteorological phenomena that can be seen as regular and ordered, such as seasonal rains, demonstrate God's providence and desire to nourish humanity, while exceptional and destructive events reflect God's anger and his desire either to strike down or to convert the wicked. Garcaeus contended that evidence for the providential and prodigious nature of meteorology was supported by experience and that a correct numeration of these signs can assist in warning us. Thus, just as Frytsche had done, Garcaeus listed rare meteorological events with coinciding significant historical moments..$^{85}$

Another learned defense of such positions is found in Wolfgang Meurer's Meteorologia, published posthumously in I606. According to the biography written by his son Christoph, Meurer studied in Italy with physicians such as Andreas Vesalius and Giambattista del Monte before being called by Melanchthon to teach at the university at Leipzig in I $543 \cdot{ }^{86}$ His views are similar in many ways to Garcaeus's

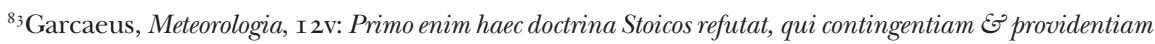
tollunt, E docet etiam contra Epicuros, hunc mundum non regi casu, nec omnia fieri necessario, nec fortuito exoriri Meteora, quorum alia producuntur ideo, ut sint signa futurorum eventuum, qualia sunt parelia, irides, halones: partim ut sint quasi instrumenta, quibus hominum ingravescentem malitiam puniat DEUS, ut sunt grandines, procellae, fulmina, terraemotus, Cometae $\mathcal{E}$ c. partim etiam ut terram suaviter rigent, aut nimium humecatam exiccent, ut sunt pluviae, nives, ros ventorum flatus $\mathcal{E} \sigma$ similia Meteora.

${ }^{8}$ Garcaeus, Meteorologia, I Iv: Est autem duplex causa finalis Meteororum. Alia est Physica, alia Theologica. Primo enim Physice loquendo, aeris mutationem significant, serenitatem, tempestatem, humiditatem vel siccitatem. In igneis etiam salus animalium spectantur. Nam per haec fumi sublati consumuntur, ne putredine omnia suffocentur $\mathcal{E}^{\mathcal{F}}$ extinguantur, qualis $\mathcal{E}^{\mathcal{O}}$ eventationis usus est in corpore humano. Quin $\mathcal{E}^{2}$ aqueis homines carere non possunt, pluvia, fluminibus fontibus, nubibus, ventis, non tantum ut aqua effundatur $\mathcal{E}^{2}$ collig-

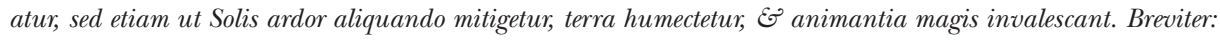
Nullum est Meteoron, quod non suam manifestam seu occultam utilitatem habeat. Hinc E Ptolemaeus inquit: Traiectiones E crinitae secundas partes habent in iudiciis, tamen ab hominibus non imprudentibus etiam earum significationes aliquo modo animadverti possunt. Deinde Theologica finalis causa est consideranda. Saepe enim Meteora praenunciant aliquid mortalibus, aut praemonent de secuturis malis, aut terrae nocent, vel utilitatem

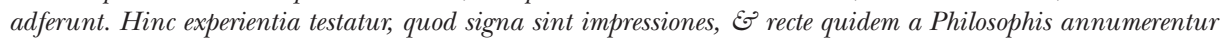
signis, sicut antea monuimus.

${ }^{8}$ Garcaeus, Meteorologia, I Iv: Hinc experientia testatur, quod signa sint impressiones, E于 recte quidem a Philosophis annumerentur signis, sicut antea monuimus. Garcaeus's list is found at $476 \mathrm{r}-482 \mathrm{v}$.

${ }^{86}$ Wolfgang Meurer, Meteorologia (Leipzig: Grossius, I 606), B8v. 
and Frytsche's, although the discussions of teleology often are accompanied by physiological explanations that pertain to health. Thus the purpose of thunder and lightning is to show the power of God and to scare the impious into becoming pious, but they also prevent disease. The final cause of comets is that they announce war, but this announcement can be explained by its heating powers, which affect human blood and lead to anger and violence. Comets are not only signs of impending plagues, but also cause them by consuming the radical moisture in humans, thereby making them susceptible to disease. Meurer's evidence includes both medical theory and the testimony of numerous histories from antiquity to more recent times that show at least the temporal relation between events, such as comets and subsequent wars. ${ }^{87}$

The emphasis on teleology and providence among Protestants should not be overstated. Those associated with Wittenberg, Leipzig, or Melanchthon were far more likely to focus on that aspect of meteorology during the sixteenth century. To a certain degree, this kind of treatment of final causation continued to be influential during the early years of the seventeenth century. Nicolaus Taurellus, for one, endorsed it. But Taurellus's attacks appear to have had a limited influence on treatments of meteorology, and by the beginning of the seventeenth century the force of this view was waning even at Wittenberg, despite the fact that prominent Lutheran theologians during the first decades of the seventeenth century, such as Johann Gerhard, associated God's providence with final causation. ${ }^{88}$ Daniel Sennert, a professor of medicine at Wittenberg and author of one of the most frequently reprinted text-books on natural philosophy of the first half of the seventeenth century, did not address the teleology of meteorology as his predecessors had; his meteorological writings scarcely mention final causation. Even when he accepted that raining milk or blood can only be supernatural, he offered that substances similar to milk and blood can fall from the sky naturally. Raining blood might not actually be blood. Furthermore, Sennert rejected Jean Bodin's assertion that thunder and lightning are demonic, arguing that they can be understood through natural causes; and he contended that Pliny's division of lightning into "prophetic" and "meaningless" was the result of superstition rather than the consideration of physical causation. ${ }^{89}$

Professors at the University of Tübingen addressed meteorology in a way that was not very different from the Italians, even as early as the middle of the sixteenth century. Jacob Schegk ( I 5 I I-I 587 ), a professor at Tübingen, in his commentary on Aristotle's Meteorology specifically wrote that there are two causes of meteorological phenomena, material and efficient. Accordingly, his commentary does not discuss final causes. Schegk's successor as ordinary professor of natural philosophy,

${ }^{87}$ Meurer, Meteorologia, 269-84.

${ }^{88} \mathrm{~J}$. Gerhard, A Golden Chaine of Divine Aphorismes [Loci communes theologici], trans. R. Winterton (Cambridge: Printers to the Universitie, I632), 66-80. For an account of Gerhard's views on providence see Preus, Theology of Post-Reformation, I:I07-43.

${ }^{89}$ Daniel Sennert, Epitome naturalis scientiae (Wittenberg: J. Helwig, I633), 355, 3 I4, 320. For Bodin, see Jean Bodin, Universae naturae theatrum (Hanau: Wechel, I605), 209-I I. For Pliny, see his Historia naturalis 2. I04. 
Georg Liebler, also did not discuss the final causes of meteorology in his textbook, Epitome philosophiae naturalis..$^{\circ}$

The ambivalence toward the role of teleology in meteorology that characterizes the Lutheran natural philosophical tradition is apparent in the work of Johannes Kepler, who had studied at the University of Tübingen. Kepler severely limited the role of God's providence in meteorology and questioned the widespread proclamations of portents in the sky. He chided those who claimed that the increasing number of eclipses was portentous for their lack of sophistication in astronomy. In fact, Kepler wrote that there are four or five eclipses that are visible somewhere on earth every year. ${ }^{91}$ In his De cometis libelli tres (I619), he attempted to establish their natural causes of comets, even though he believed they were portentous. ${ }^{92}$ Moreover, his unwillingness to make predictions in his De fundamentis astrologiae certioribus ( $\mathrm{I} 602$ ) about upcoming harvests was reaffirmed by his belief that despite God's providence, "the harvest partly depends on accidental causes," which "are, by their very nature, not predictable." ${ }^{93}$ Nevertheless, Kepler saw the universe as ordered by God's mind, in a manner similar to Melanchthon. ${ }^{94}$ This order, however, included accidental causes that were irregular and unpredictable.

$$
5 \text {. }
$$

Discussions of teleology in a meteorological context connected understandings of the order of nature with religious meanings, which brought answers to ethical questions. Natural philosophy, according to Pomponazzi, as was the case for a number of Catholic theologians from at least the time of Albertus Magnus, could not answer some fundamentally theological issues. ${ }^{95}$ For Pomponazzi, the final causes of contingents were unknowable through an examination of nature, even if they were ultimately determined by an inscrutable God, who knows their purpose as well as ultimately being their creator. While an understanding of God's purposes might be beyond human capacities, the purpose of the cycles of weather and even natural disasters was found in their role in God's ordering of the universe. Pomponazzi's emphasis on issues of contingency, chance, and the cyclical nature of generation and destruction emerged in part from the desire to render Aristotle's system coherent and complete.

\footnotetext{
${ }^{9} \mathrm{G}$ Georg Liebler, Epitome philosophiae naturalis, ex Aristotelis summi philosophi libris ita excerpta (Basel: Oporinus, I 56I), I 86-222.

9IJ. V. Field, "A Lutheran Astrologer: Johannes Kepler" ["A Lutheran Astrologer"], Archive for History of Exact Sciences 3I (I984): I 89-272, at 263.

${ }_{92}^{2}$ Patrick J. Boner, "Kepler on the Origins of Comets: Applying Earthly Knowledge to Celestial Events," Nuncius 2I (2006): 3 I-47, at 46; Schechner Genuth, Comets, I00-OI

${ }^{93}$ Field, "A Lutheran Astrologer," 263.

${ }^{94}$ Methuen, Kepler's Tübingen, 208; Natacha Fabbri, Cosmologia e armonia in Kepler e Mersenne: Contrappunto a due voci sul tema dell'Harmonice mundi (Florence: Olschki, 2003), I I4-33. For the view that Kepler thought "teleologically," see Rudolf Haase, "Kepler's Harmonies, between Pansophia and Mathesis Universalis," in Kepler: Four Hundred Years, ed. Arthur Beer and Peter Beer (Oxford: Pergamon, I975), 519-33, at 528-29. For the view that he emphasized efficient causes, see Job Kozhamthadam, S.J., The Discovery of Kepler's Laws: The Interaction of Science, Philosophy, and Religion (Notre Dame, IN: Notre Dame University Press, I994), 65-68.

${ }_{95}^{95}$ Ian Maclean, "Heterodoxy in Natural Philosophy and Medicine: Pietro Pomponazzi, Guglielmo Gratarolo, Girolamo Cardano," 7-I6.
} 
The moral questions that arise out of the study of meteorology, however, have less to do with Aristotle than with Christianity and Stoic philosophy. Even if Pomponazzi rejected the absolute determinism of the Stoics, their view of the role of natural philosophy in ethics was attractive to him. Consideration of the order of nature, of natural things and their unceasing generation and destruction leads to mental security.

Here Seneca says a good and true thing. For he says that he is more secure, who knows that he is secure nowhere. ... Therefore they [philosophers] know that it is not possible to evade the order of God in town, kingdom, or city; or in wealth or luxury; or by good advice. Therefore they dismiss all temporal matters and even mores, and they investigate the divine and contemplate the best and greatest God, who disposes and who makes so wisely these effects. Therefore they contemplate the causes of natural things and how God makes them the best and most ordered by his disposition..${ }^{96}$

Investigating the causes of fleeting meteorological effects makes philosophers more secure because they know the inevitability of destruction and that this destruction is part of the divine design of an orderly and ideal universe.

For many Lutherans, meteorology showed the will and order of an all powerful God but did not necessarily bring security by demonstrating the inevitable destruction of everything temporal. Rather, the weather was a courier by which God expressed himself. Each kind of meteorological event had its own specific message that indicated God's providence or anger. Meteorological effects were not always comforting; they could be spurs to conversion or pious living, as was the case for lightning and thunder. Knowledge of the natural causes of rare and strange, seemingly prodigious, events, such as the alleged raining of animals or bodily fluids, did not lead to a more secure existence. Security lay in knowing the theological significance of these events, that their increase in number was evidence of the coming of the apocalypse and proof of the righteousness of the Lutheran faith. ${ }^{97}$

${ }^{9}$ Pomponazzi, In libros Meteororum, 8ov: Hic dicit Seneca unum bonum verum. dicit enim, illum esse securiorem qui scit nullibi se esse securum; Ideo Philosophi sunt securissimi, quoniam ipsi sciunt haec omnia ex ordinatione naturae evenire, ideo non mirantur de illis effectibus, ut facit ignobilis vulgus; quoniam horum effectuum causas cognoscunt; et ita esse ordinatum optime a natura, Ideo sciunt se positam et ordinationem Dei castro, regno, civitate, aut in divitiis, voluptatibus, aut propriis consiliis non posse evadere; Ideo spernunt omnia temporalia, et etiam morem, diliguntque divina et contemplantur Deum optimum maximum, qui hos effectus tam sapienter disposuit, et qui fecit: Ideo contemplantur causas rerum naturalium, et quomodo Deus illae optime et ordinatissime dispositione facit.

${ }^{97}$ I thank the journal's referees, Gideon Yaffe, and Andrew Sparling for their comments, criticisms, and references. Research and writing of this paper was funded by a Gladys Krieble Delmas Foundation Fellowship, an FWO fellowship held at the Katholieke Universiteit Leuven, an Oakland University URC Faculty Fellowship, and a Dibner History of Science Program Fellowship at the Huntington Library. 